\title{
Archaeological Testing of Sites 41CJ75 and 41CJ76 Comanche County, Texas
}

Wayne C. Young

Follow this and additional works at: https://scholarworks.sfasu.edu/ita

Part of the American Material Culture Commons, Archaeological Anthropology Commons, Environmental Studies Commons, Other American Studies Commons, Other Arts and Humanities Commons, Other History of Art, Architecture, and Archaeology Commons, and the United States History Commons

Tell us how this article helped you.

This Article is brought to you for free and open access by the Center for Regional Heritage Research at SFA ScholarWorks. It has been accepted for inclusion in Index of Texas Archaeology: Open Access Gray Literature from the Lone Star State by an authorized editor of SFA ScholarWorks. For more information, please contact cdsscholarworks@sfasu.edu. 


\section{Archaeological Testing of Sites 41CJ75 and 41CJ76 Comanche County, Texas}

\section{Licensing Statement}

This is a work produced for the Texas Department of Transportation (TxDOT) by the report producer. TxDOT and the report producer jointly own all rights, title, and interest in and to all intellectual property developed under TXDOT's contract with the report producer. The report may be cited and brief passages from this publication may be reproduced without permission provided that credit is given to both TxDOT and the report producer. Permission to reprint an entire chapter, section, figures or tables must be obtained in advance from either the Supervisor of the Archeological Studies Branch, Environmental Affairs Division, Texas Department of Transportation, 125 East 11th Street, Austin, Texas, 78701 or from the report producer. 
ARCHAEOLOGICAL TESTING

OF SITES 41CJ75 and 41CJ76

COMANCHE COUNTY, TEXAS

by

WAYNE C. YOUNG

Texas

State Department of Highways and Public Transportation Highway Design Division

November, 1987 
ABSTRACT

Archaeological testing of two sites in western Comanche County, 41CJ75 and 41CJ76, by the State Department of Highways and Public Transportation (SDHPT) during April 1987 has shown that both sites are shallow, low density, prehistoric campsites. Portions of both sites outside the right-of-way of SH 36 have been impacted by cultivation and site integrity has been lost. Those portions within the right-of-way are located within steep backslopes which made testing difficult. Site 41CJ75 was found to be only $10 \mathrm{~cm}$ deep except where the SDHPT had placed recent fill on the site. Site 41CJ76 was located alohg a very steep backslope where excavation of $10 \mathrm{~cm}$ levels within a 1 by 1 meter unit was impossible. Tests suggest that the maximum site depth within the right-of-way was $40 \mathrm{~cm}$ with the maximum density of prehistoric materials 10 to $20 \mathrm{~cm}$ below the original surface. A basal red clay beneath a brownish sand was found to be culturally sterile. Ongoing wind erosion in the recently plowed fields adjacent to the right-of-way has revealed this red clay in the furrows, suggesting that the site has been largely destroyed. Neither site appears to be eligible for nomination to the National Register of Historic Places or for consideration as a State Archaeological Landmark. No further research is recommended for either site. 
TABLE OF CONTENTS

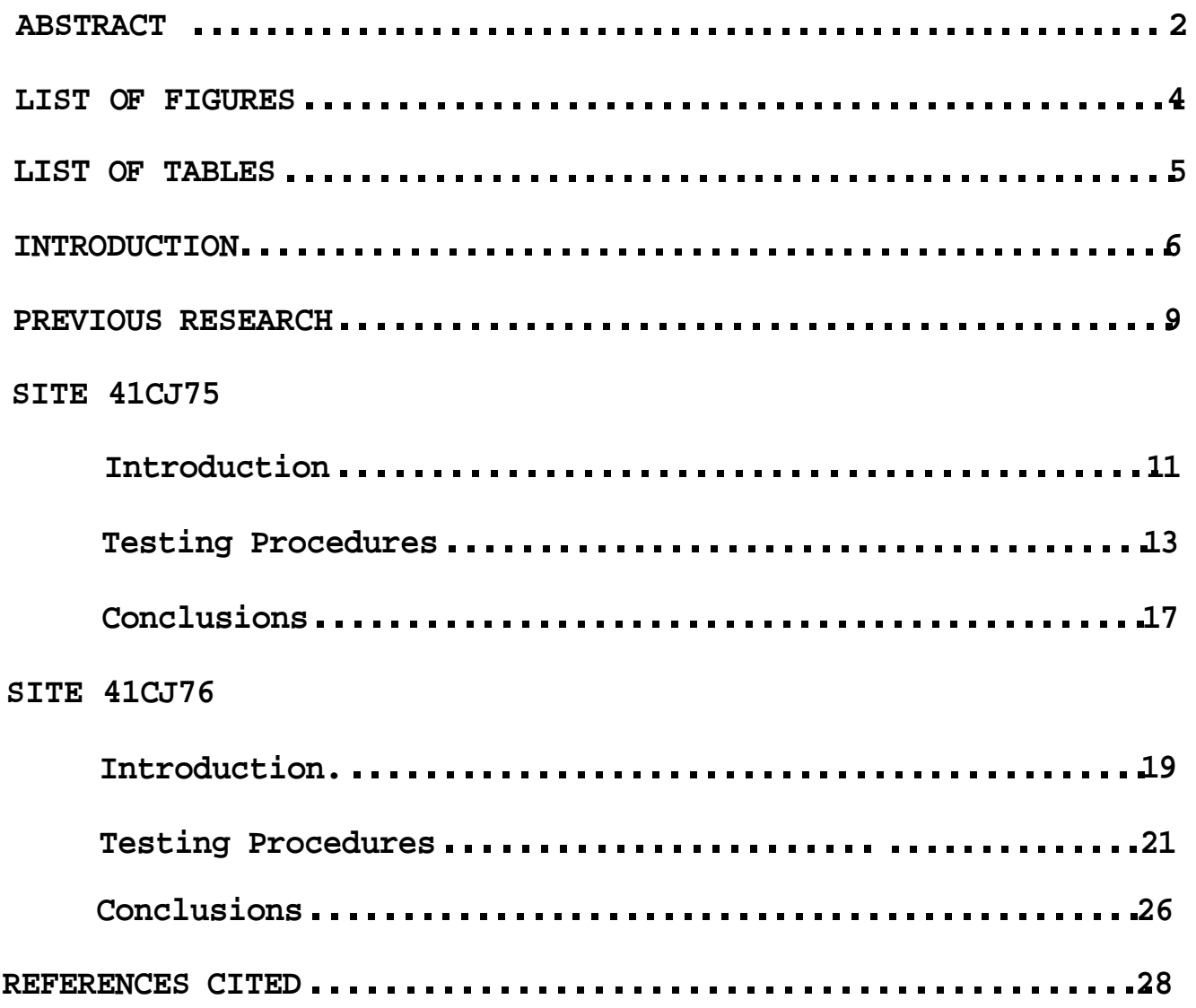




\section{LIST OF FIGURES}

FIGURE 1. Location map of Sites $41 \mathrm{CJ} 75$ and $41 \mathrm{CJ} 76$ in Comanche

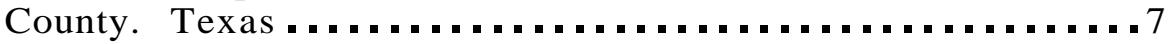

FIGURE 2. Map of Site $41 \mathrm{CJ} 75$ showing location of test units....14

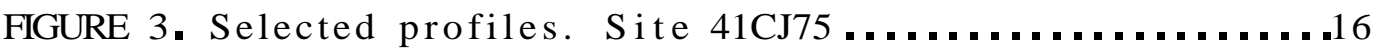

FIGURE 4. Map of Site 41CJ76 showing location of test units....22

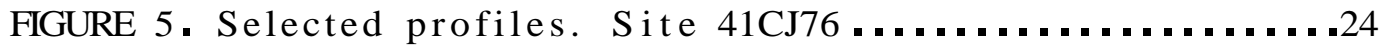




\section{LIST OF TABLES}

TABLE 1. Lithic debris from $41675 \ldots \ldots \ldots \ldots \ldots \ldots \ldots \ldots \ldots \ldots$

TABLE 2. Lithic debris from 41CJ76.....................26 
INTRODUCTION

Archaeological Sites 41 CJ75 and 41 CJ76 are located in western Comanche County along State Highway 36 (Fig. 1). The sites were discovered and recorded in 1983 by Daymond Crawford of the SDHPT archaeology section during a routine survey of proposed improvements to SH 36. The presence of the sites was indicated by the occurrence of flint flakes eroding from the backslopes of the road cut. The sites were recorded at the Balcones Research Center at the University of Texas at Austin and testing was recommended. No diagnostic artifacts or features were observed but the location of the flake debitage suggested that some depth might be involved.

The archaeological survey was performed because of plans by the Department to widen the driving lanes of $\mathrm{SH} 36$ from 20 to 26 feet and to rework the highway backslopes where hills have been cut. The original construction plans called for reworking 10 miles of highway between Comanche and the Eastland County line. Subsequent plans divided the project into two segments with the first phase scheduled to begin in August 1987. Neither site is located in this segment and is not scheduled to be impacted for a number of years. Preliminary plans call for the purchase of approximately 10 feet of new right-of-way on both site locations. Testing was conducted within the existing right-of-way and examination of the ground surface with the proposed right-of-way suggests that intact cultural deposits are unlikely to exist in future impact areas. 


\section{This Page Redacted Per THC Policy}


Testing was conducted under the Memorandum of Understanding (36 C.F.R., Part 800), procedures prescribed and endorsed by the Federal Highway Administration. Testing goals were to determine the significance, cultural age, depth of the cultural deposits, and eligibility for nomination to the National Register of Historic Places. Testing was performed April 13-17, 1987 under the direction of Wayne C. Young of the Department's professional cultural resources staff with field assistance from the Brownwood District (District23) Comanche resident engineers office. Eight person days were expended testing the sites. 
PREVIOUS RESEARCH

An examination of published reports for Comanche and adjacent counties indicates that some previous archaeological research has been done in this portion of north-central Texas and that the area shows more similarities to the Central Texas Archaeological Region than to complexes found farther north and west. This section briefly discusses the previous archaeological research in Comanche, Eastland, Erath, Brown, Hamilton, and Mills Counties.

The earliest published archaeological material for Comanche County is the work of Straley (1909) dealing with Indian village sites near Comanche. This work was followed by Runkles (1930) describing some artifacts from the county. Thirty-four years later, Prewitt (1964) reported on the largest excavation in the county, the Terri and Lightfoot Sites. During the 1970's research centered on the Rush Creek Watershed with reports by Whitsett and Shafer (1975), and McNutt and Lord (1978). Research on the Rush Creek Watershed continued into the 1980's with Cole (1983) reporting on Soil Conservation dams along that drainage. Chandler( 1984) reported on metal projectile points from the county.

Less published archaeological research exists for Eastland County. The two published works are Thoms and Montgomery (1977) on a survey of the Brazos River basin and Cole (1979) dealing with SCS structures in the county. There have been no large scale excavations in Eastland County. 
Research in Erath County began with Ray (1931) reporting on artifacts found in the county. The county lay archaeologically dormant until the late 1970's when coal mining began in the area. Research relating to coal leases includes Skinner (1978) and (1983). Virtually nothing is known on the resources of the county as a whole.

Brown County has been the subject of more research. The initial archaeological publication was by Ray (1933) dealing with the Brownwood Skull. Campbell (1952) reported on early excavations near Brownwood. Nothing more was published until the mid 1970's when the SCS began planning floodwater retarding structures in the county. Shafer (1975) Shafer, Baxter, and Dering (1975), and Kirby and Moir (1976) represent the major published research in the 1970's. The most recent research appears to be by Prewitt and Associates, Inc. (1983).

At least 7 publications have dealt with Hamilton County and most of these are early for Texas archaeological literature. The earliest is Jackson (1930), followed by Horne (1938), Kirkland (1938), and Watt (1940). Campbell (1952) also dealt with the archaeology of Hamilton County. Recent research is represented by the surveys of Shafer and Whitsett (1975) and Moore (1985).

Mills County is barely represented in the published archaeological record with the only publication being by Cole (1980) on a SCS project. Only 8 sites have been recorded in the county (Biesaart, Roberson, and Spotts: 1985) 
Introduction

Archaeological Site 41CJ75 is located approximately 7 miles northwest of Comanche, Texas along SH 36. The site is situated along the eastern slope of a hill about 300 meters northwest of the highway bridge over Sweetwater Creek. FM 589 joins SH 36 about 100 meters east of the site area (Pig. 1). The site is situated along the first major rise from a fairly wide floodplain and appears to be limited to the eastern slope of the hill. Flakes visible on the surface suggest a site size approaching 70 meters along the highway right-of-way .

Vegetation along Sweetwater Creek includes willow, pecan, hackberries, and elm in a galleria forest following the creek banks. The floodplain between the creek and the site is currently an improved pasture. The edge of the hill slope contains a number of mesquite and elm trees before giving way to a short grass prairie which covers the rolling uplands in the site area. These upland areas are dominated by native grasses with widely scattered post oak trees.

Soils in the site area consist of an upper layer of brown to reddish sand or sandy clay overlying a red basal clay. The lower portion of the sandy zone contains a quantity of $\mathrm{CaCO}_{\mathbf{3}}$ pebbles which gradually increase in frequency until the clay zone is reached. There are few caliche pebbles within the clay zone. The sandy zone is thickest at the base of the hill where it is about $60 \mathrm{~cm}$ thick. This zone decreases in 
thickness as the hill rises until is nonexistent near the crest. Wind erosion has removed this zone from the upper reaches of the site. The sandy soil zone is also missing immediately north of the right-of-way in a terraced, native grass pasture. 
Testing Procedures

Testing of Site 41 CJ75 began with an examination for prehistoric cultural debitage. This examination revealed a thin scatter of flint flakes visible along the north right-of-way on the east side of the hill (Fig. 2. The highway roadbed had been deeply cut through the hillside and a steep backslope extended to within 1.5 meters of the right-of-way fence line. A few flakes were observed in the north backslope with more showing on the surface immediately north of the fence in a 70 meter long strip. The south right-of-way appeared to be culturally sterile.

Testing was conducted by hand excavation of three 1 meter square test units into the narrow strip between the top of the backslope and the north right-of-way fence line. Vertical contrbl was maintained in $10 \mathrm{~cm}$ deep levels dug from the existing ground surface and measured from the corners of each unit. All excavated soil was passed through $1 / 4$ inch mesh screen and recovered materials were bagged and labeled by test unit and level coordinates. Cultural materials were removed from the site to the SDHPT Archaeology Laboratory for processing, analysis, and temporary storage.

Test Unit 1 was the westernmost square excavated into 41CJ75 and was located near the western, or uphill, limits of exposed flake debitage (Fig. 2. Two $10 \mathrm{~cm}$ levels were removed. Level 1 consisted largely of a berm placed on top of the backslope by SDHPT maintenance activities. This level consisted of a red sandy clay. Level 2 was excavated in two roughly equal units with the top half containing the red sandy clay and 


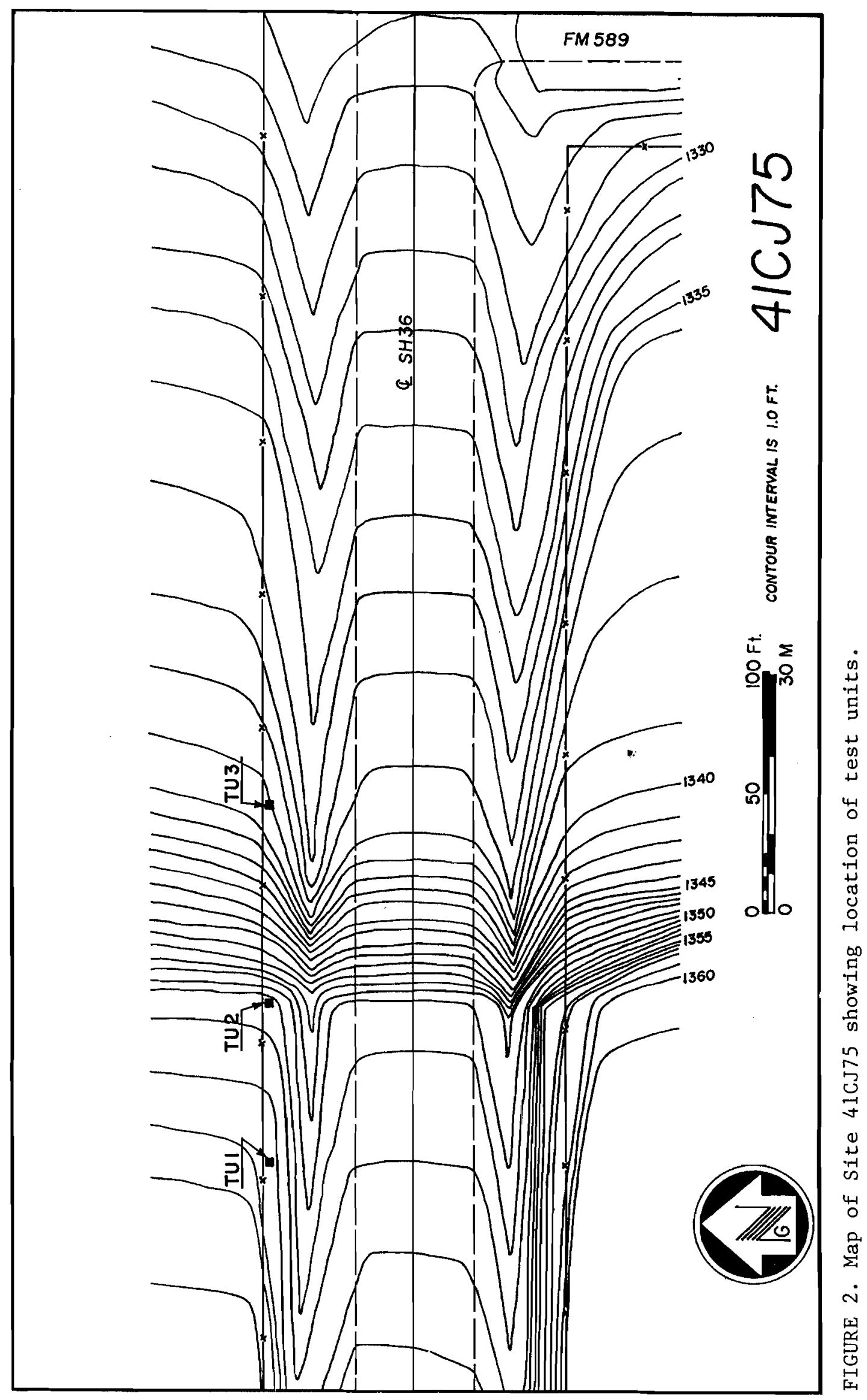


the lower half containing a red clay (Fig.3). This level was split to determine if cultural materials were present in the red clay. Level 1 contained 1 "tin" can similar in size and shape to tuna fish cans and no flakes. Level 2 contained 6 flakes, 1 flat metal washer, and 1 small glass fragment. The red clay was found to be culturally sterile.

Test Unit 2 was located near the center of the exposed flakes and was 16 meters east of Test Unit 1 and about midwaydown the slope. Three 10 am thick levels were excavated. Level 1 contained a brown sandy clay. Level 2 was a brown sandy clay with numerous caliche pebbles and level 3 contained a brown sandy clay with caliche to a depth of $28 \mathrm{~cm}$ below the present surface (Fig. 3). The lower 2 an of level 3 contained a red clay. There was no indication of a berm. Level 1 contained 8 flakes and a broken clear glass jar rim. Levels 2 and 3 were culturally sterile.

Test Unit 3 was located at the eastern extent of surface lithic debitage and was near the base of the hill. This one meter square was located 20 meters east of Test Unit 2. Excavations were carried to a depth of 40 cm. Level 1 was within a berm from maintenance activities and was a light brown sand (Fig. 3). Level 2 was a tan sand and levels 3 and 4 were the same light brown sand seen in level 1 . Level 1 contained 2 flakes, level 2 had 9 flakes and $\mathbf{3}$ and 4 were culturally sterile. 


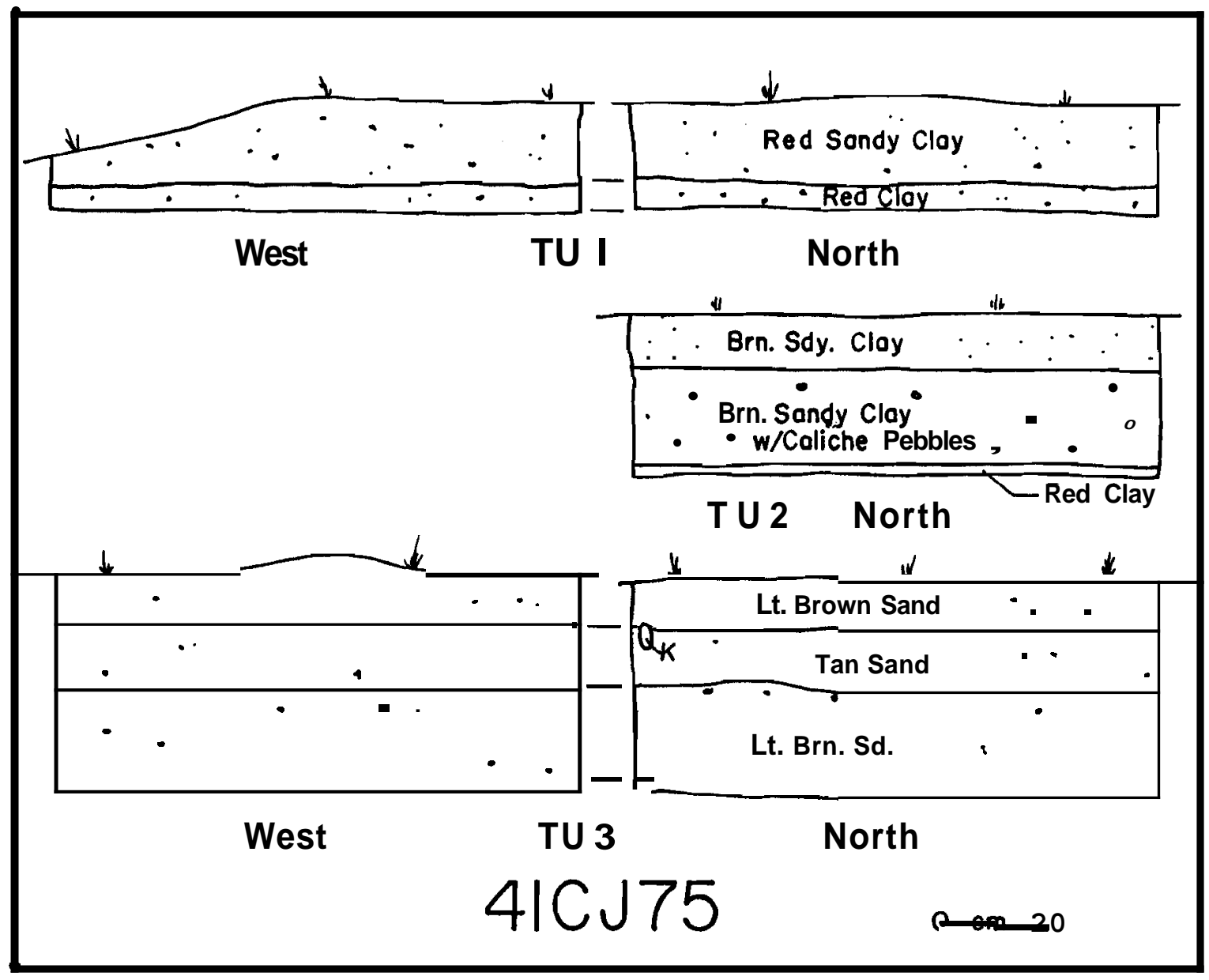

FIGURE 3. Selected profiles, Site 41CJ75. 
Conclusions

Three one by one meter units were excavated into $41 \mathrm{CJ} 75$ and nine $10 \mathrm{~cm}$ deep levels were removed. A total of 25 flint flakes were recovered as shown in Table 1. Cultural materials were found to be limited to the upper $20 \mathrm{~m}$ with levels 3 and 4 being culturally sterile. Test Units 1 and 3 also contained obvious berms created by the SDHPT during drainage ditch cleaning. These berms were excavated and largely equate to level 1 in the excavations. In reality, level 2 of Test Units 1 and 3 represent the original ground surface. Under these considerations, the original first level would contain all of the recovered debitage from the site.

Table 1: Lithic debris from 41CJ75.

\begin{tabular}{c|c|c|c|c}
\hline Level & Test 1 & Test 2 & Test 3 & Total \\
\hline 1 & 0 & 8 & 2 & 10 \\
2 & 6 & 0 & 9 & 15 \\
3 & & 0 & 0 & 0 \\
4 & & & 0 & 0 \\
\hline
\end{tabular}

No diagnostic artifacts, prehistoric tools, or cultural features were recovered. Testing data suggests that the site is of low density as evidenced by the small quantity of recovered materials and the thin surface scatter of lithic debris outside the right-of-way. The site is also limited to the upper $20 \mathrm{~cm}$ of the soil deposits or more properly, the uppermost $10 \mathrm{~cm}$ of original soil. The portions of $41 \mathrm{CJ} 75$ within the present right-of-way do not meet the requirements for eligibility to the 
National Register of Historic Places. The proposed right-of-way has obviously been terraced and this has effectively destroyed the site integrity. This area also fails to meet the criteria for eligibility to the National Register of Historic Places. 
Introduction

Archaeological Site $41 C J 76$ is located about 11 miles northwest of Comanche, Texas, along SH 36 (Fig. 1). The site is about 150 meters east of Stag Creek and 20 meters east of the junction of FM 1477 with SH 36. It occupies a hill marking the transition from a narrow floodplain along the east side of Stag Creek to a rolling uplands and is largely limited to the western slope of the hill. Observations of lithic debitage suggests that the site is limited to the north side of $\mathrm{SH} 36$ and that it covers an area about 100 meters along the highway.

Vegetation along Stag Creek consists of a galleria forest of willow, pecan, elm, hackberries, greenbriars, and tall native grasses. The upland area is rolling short grass prairie with widely scattered post oaks. The site immediately north of the right-of-way is presently in cultivation. The right-of-way supports a luxuriant growth of wild flowers dominated by bluebonnets and evening primrose.

Soils on the site area consist of a light brown sand extending to depths of $60 \mathrm{~cm}$. Immediately beneath this zone is a culturally sterile red clay. Occasional sandstone fragments occur at the contact of the sandy soil with the clay. A similar soil zone is present along the creek bank with the creek slightly embedded into red clays. Soils appear to be shallower in the plowed field as basal clays can be seen in some of the 
plow furrows. The sandy soils are highly susceptible to wind erosion and some of the upper zone appears to have been blown away. 
Testing Operations

Testing of Site 41CJ76 began with a thorough surface examination of the backslopes and right-of-way edges. This examination showed that the site extended about 100 meters along the north side of the right-of-way and that the south right-of-way was void of prehistoric cultural materials. It also indicated that the north backslope had been cut at a steep angle to the fence line and that a drop of 6 feet in 12 horizontal feet from the right-of-way line was average for the site area (Fig. 4). There was no portion of the present right-of-way which had not been impacted by previous construction and maintenance.

Testing was accomplished by the excavation of four 1 meter square units along the north right-of-way line. These units were staked out as one meter squares with the right-of-way as the north wall. Three of the four units reached basal clay before their width reached one meter. Vertical control was maintained by digging $10 \mathrm{~cm}$ deep levels with measurements from the north wall. This procedure resulted in levels of varying volume due to the angle of the backslope and allowed the inclusion of some historic materials in almost all levels, but seemed preferable to excavating along an obviously artificial backslope. In 3 of the 4 test units, each level contained roughly twice the soil volume of the preceding level. Test Unit 4 is the exception where levels are of roughly equal volume below level 1 .

Test Unit 1 was located in the center of the flake concentration and was 65.5 meters east of the intersection of FM 1477 and SH 36 (Fig. 4). Six 


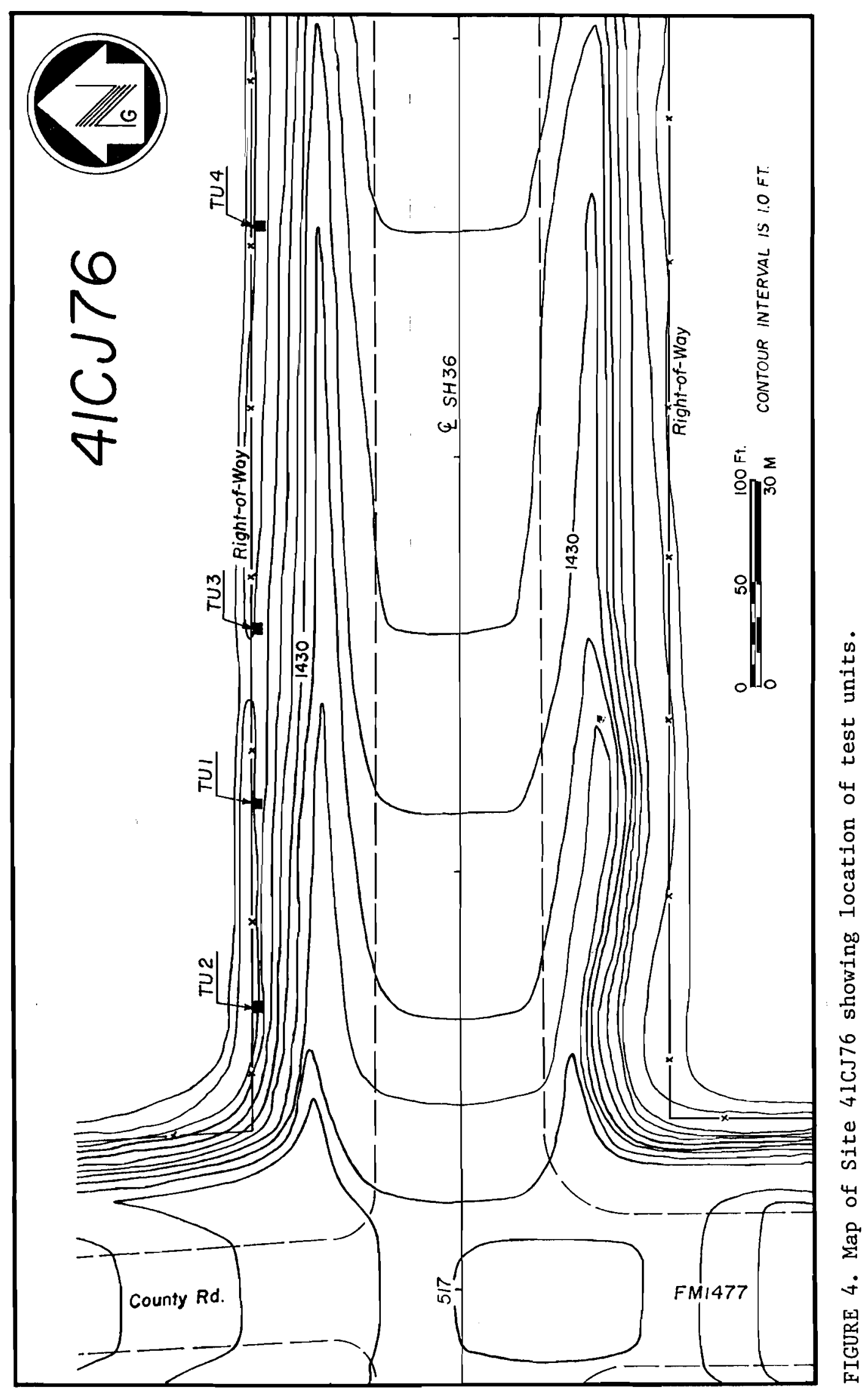


$10 \mathrm{~cm}$ deep levels were removed with levels 1-5 being in light brown sand and level 6 in red clay (Figure 5). Level 1 was sterile. Level 2 contained 13 flakes, 2 metal fragments, 2 glass sherds, and a plate fragment. Level 3 contained 8 flakes, a side scraper, 4 glass sherds, and 6 can fragments. Level 4 contained 8 flakes, a plate fragment, and 3 can fragments. Levels 5 and 6 were culturally sterile.

Test Unit 2 was the westernmost unit and was located 15 meters west of Test Unit 1 Fig. 4. Six levels were excavated with the upper $55 \mathrm{~cm}$ being light brown sand and the lower $5 \mathrm{~cm}$ being red clay (Fig. 5). Level 1 contained 2 flakes, 1 nail, 55 glass sherds, and 2 metal fragments. Level 2 yielded 6 flakes, the edge of a thick biface, 18 glass fragments, and 4 can fragments. Level 3 contained 16 flakes, a crock fragment, 15 glass sherds, 1 cut nail, and 10 metalfragments. Level 4 contained 11 flakes and 5 metal fragments. Levels 5 and 6 were culturally sterile.

Test Unit 3 was 13 meters east of Test Unit 1 in the main flake concentration. Five levels were dug with $40 \mathrm{~cm}$ of light brown sand over $10 \mathrm{~cm}$ of red clay (Fig. 5. Level 1 contained 1 flake, 1 can, 1 staple, and 3 metal fragments. Level 2 yielded 5 flakes, 1 skillet handle, 1 wire fragment, 1 staple, 2 glass sherds, and 11 metal fragments. Level 3 contained 2 flakes. Level 4 produced 7 flakes, 1 complete bottle, 1 fence staple, 1 plate fragment, and 1 metal fragment. Level 5 was culturally sterile. 


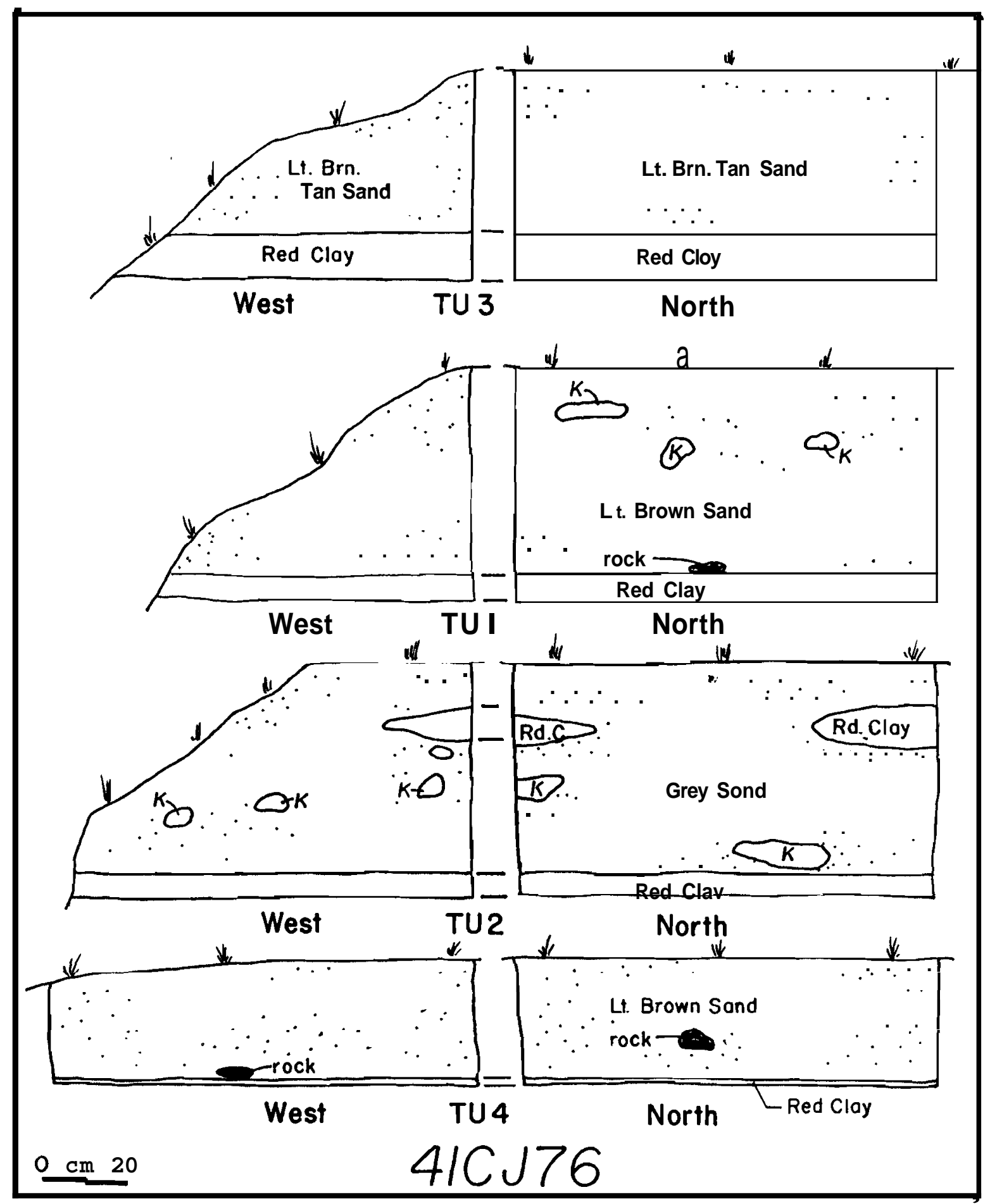

FIGURE 5. Selected profiles, Site 41CJ76. 
Test Unit 4 was the easternmost square excavated and was 29.5 meters east of Test Unit 3 (Fig. 4). Three levels were removed with the upper $25 \mathrm{~cm}$ in light brown sand and the lower $5 \mathrm{~cm}$ in red clay. Levels 1 and 3 were sterile while level 2 contained 6 flakes. 
Conclusions

Archaeological Site 41CJ76 was tested with four 1 meter square units dug into a steep backslope. Vertical control was maintained in $10 \mathrm{~cm}$ levels measured from the right-of-way edge. Due to the angle of the backslope, volumes of levels could not be controlled for a direct comparison with each other. Each level had a greater excavated volume than the level above it.

Table 2 lists the provenience of prehistoric debitage recovered from 41CJ76 and indicates that the site occurs in levels 2, 3, and 4 . Since the frequency peak is in level 2 in 3 of the 4 units and since level 2 has about $1 / 2$ the volume of level 3 , it may be assumed that this is the major occupational zone within the site.

Table 2: Lithic debris from 41CJ76.

\begin{tabular}{c|c|c|c|c|c}
\hline Level & Test 1 & Test 2 & Test 3 & Test 4 & Total \\
\hline 1 & 0 & 2 & 1 & 0 & 3 \\
2 & 13 & 7 & 6 & 6 & 32 \\
3 & 9 & 16 & 2 & 0 & 27 \\
4 & 8 & 11 & 7 & & 26 \\
5 & 0 & 0 & 0 & & 0 \\
6 & 0 & 0 & & & 0 \\
\hline
\end{tabular}

No prehistoric lithic debitage was recovered from the red clay zone which was normally found $50-60 \mathrm{~cm}$ below the ground surface. The ground surface along the right-of-way is higher than in the plowed field immediately north of it due to wind erosion and possibly to some accumulation of soil by plowing. The depth to the red clay is less in the 
field than along the right-of-way as attested by the red clay showing in the fresh plow furrows.

Since the site has been plowed into the sterile red clay, it may be assumed that the portion of the site within the field has been either destroyed or severely damaged by deep plowing. Future plans by the SDHPT to purchase a small part of this field for right-of-way should not adversely affect the site.

Portions of $41 \mathrm{CJ} 76$ within the present and projected right-of-way are not considered eligible for consideration as a State Archaeological Landmark or nomination to the National Register of Historic Places due to damages caused by highway construction and maintenance and ongoing farming activities. 
REFERENCES CITED

Biessart, Lynne A., Wayne R. Roberson, and Lisa Clinton Spotts

1985 Prehistoric Archaeological Sites in Texas: A Statistical Overview. Office of the State Archeologist Special Report 28.

Campbell, T. N.

1952 Early Archeological Excavations in the Vicinity of Brownwood, Texas. The Record 10(3):10-14.

Chandler, C. K.

1984 Two Metal Projectile Points from Central Texas. La Tierra, Vol. 11, No. 3, pp.13-16.

Cole, Nancy Mottashed

1979 Lake Leon Critical Area Treatment A Measure, Leon-Bosque RC \&D Area, Eastland County, Texas. Archeological and Historical Survey Report. Soil Conservation Service.

1980 Archeological and Historical Survey of a Critical Area Treatment on the Brayton Smith Property in the NE Laterals Subwatershed of the Middle Colorado River Watershed, Mills County, Texas. Soil Conservation Service.

1983 Archeological and Historical Survey of Floodwater Retarding Structure 6A, Rush Creek Watershed, Comanche County, Texas. Soil Conservation Service.

Horne, Sam

1938 A Hamilton County Cache. Bulletin of the Central Texas Archeological Society, No. 2,pp.43.

Jackson, A. T.

1930 Reconnaissance in Hamilton County. Unpublished MS on file at Texas Archeological Research Laboratory, Balcones Research Center, the University of Texas at Austin.

Kirby, Foster E. and Randy Moir

1976 Brownwood Dam Modification: An Archaeological Assessment. Archaeology Research Program. Reports in Archaeology 95. Southern Methodist University.

Kirkland, Forrest

1938 An Archeology Survey of the Cranfills Gap Area. Central Texas Archeologist. No. 4,pp. 71-84.

McNatt, Logan and Ken Lord

1978 An Archeological Assessment of Sites 41CJ62, 41CJ69, and 41CJ71, Rush Creek Watershed, Comanche County, Texas. Report No. 45, Anthropology Laboratory. Texas A\&M Research Foundation. 
Moore, Bill

1985 A Cultural Resources Survey of the Proposed Pecan Creek Park, Hamilton County, Texas. Archeological Research Laboratory, Texas A\&M University.

Prewiit, Elton R.

1964 Excavations at the Terri and Lightfoot Sites, Proctor Reservoir, Comanche County, Texas. Bulletin of the Texas Archeological Society 35:143-187.

Prewitt and Associates, Inc.

1983 Archeological Survey of the City of Brownwood Proposed Sanitary Landfill Site, Brown County, Texas. Letter Report No. 196.

Ray, Cyrus

1931 Recent Archeological Researches in the Abilene Section. Bulletin of the Texas Archeological and Paleontological Society, 3:76-89.

1933 The Brownwood Skull. Bulletin of the Texas Archeological and Paleontological Society 5:95-98.

Runkles, Frank A.

1938 Indian Artifacts of Comanche County, Texas. Bulletin of the Central Texas Archeological Society, No. 2,pp.70-73.

Shafer, Harry J. Edward P. Baxter, and Phil Dering

1975 Brownwood Laterals Watershed, Brown County, Texas. An Archeological Survey of Structures 1, 2, 2A, 5, 18, 24, and 26. Report No. 13, Anthropology Laboratory, Texas A\&M University.

1975 Upper Pecan Bayou Watershed, Brown County, Texas, An Archeological Survey of Floodwater Retarding Structure No. 30. Report No. 11, Anthropology Laboratory, Texas A\&M University.

Shafer, Harry J., and and Hayden Whitsett

1975 Pecan Creek Watershed, Hamilton County, Texas, Archeological Surveys of Structures Nos 1, 2, and 4. Report No. 9, Anthropology Laboratory, Texas A\&M University.

Skinner, S. Alan

1978 Archaeology of the Thurber Coal Lease. Archaeology Research Program. Southern Methodist University.

1983 Archaeological Survey of the Lost Valley Lease (Prepared for Texas Industries Inc., Dallas). Environmental Consultants Inc. Dallas.

Straley, W.

1909 Indian Village Sites near Comanche, Texas. The Archeological Bulletin 1(1):13-15. 
Thoms, A.V., and John L. Montgomery

1977 The Archeological Resources of the Brazos River Basin: A Summary Statement. Department of Anthropology, Texas Tech University.

Watt, Frank H.

1940 Waco Area: Conclusions Based on Recent Work. Texas Archeological News 2:11-12.

Whitsett, Hayden, and Harry J. Shafer

1975 Rush Creek Watershed, Comanche County, Texas. An Archeological Survey of Floodwater Retarding Structures Nos 1, 2, and 3. Report No. 10, Anthropology Laboratory. Texas A\&M University. 